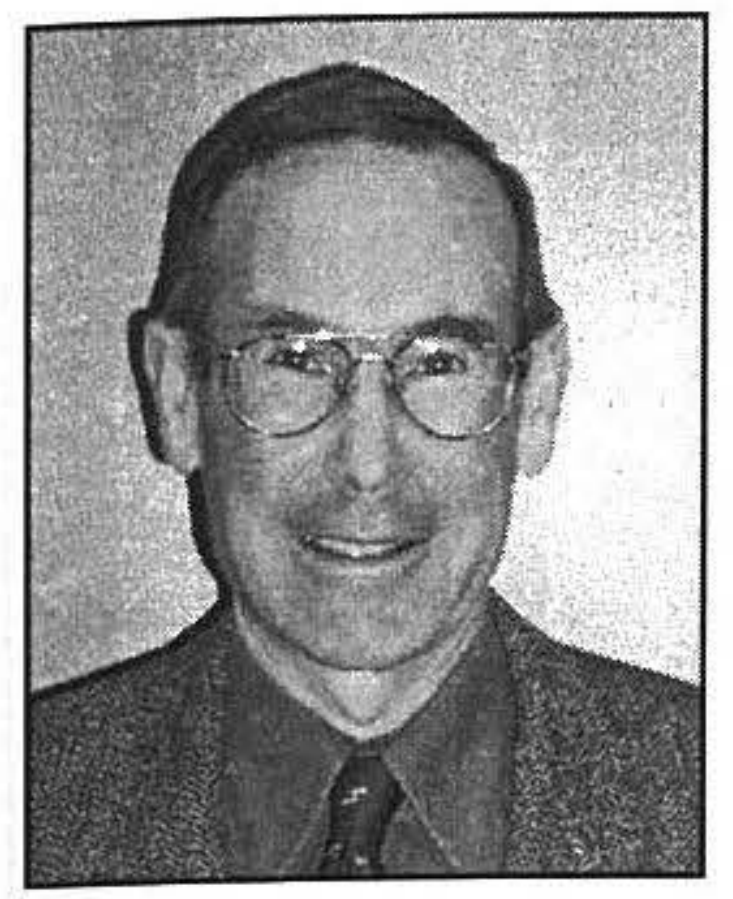

\title{
THE NEW ZEALAND LABOUR MARKET: RECENT TRENDS AND FUTURE PROSPECTS
}

\author{
Patrick Conway and Nick Carroll ${ }^{1}$ \\ Labour Market Policy Group \\ Department of Labour
}

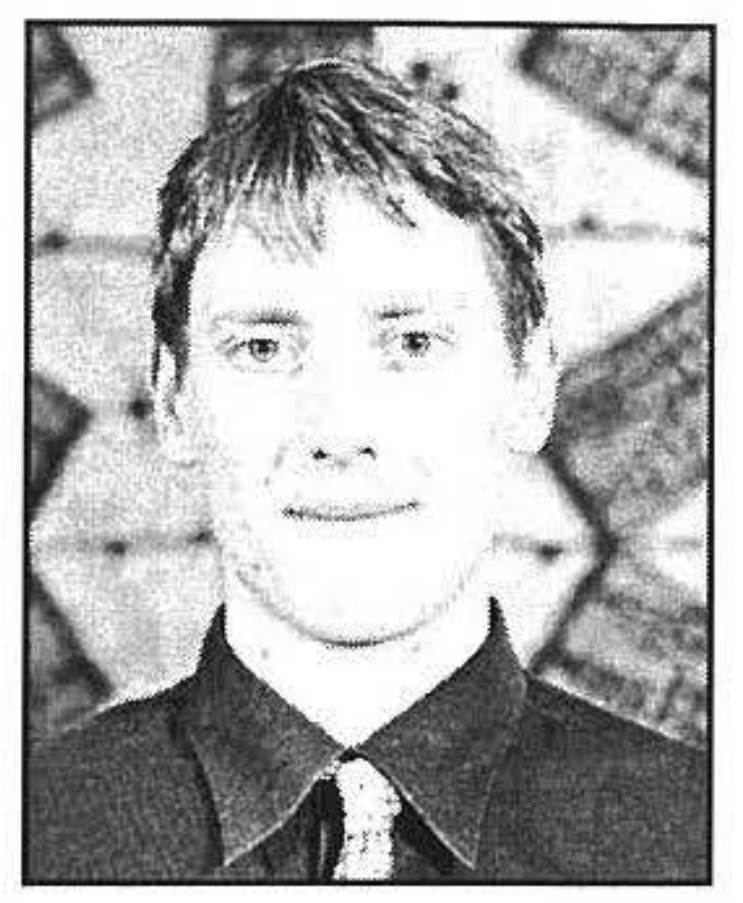

\begin{abstract}
This paper outlines developments over the past 15 years in the New Zealand labour market, concentrating on the recent period, and discusses the likely outlook for the next few years. Changes in the labour market in the past two years have, to varying degrees, reflected recovery in the New Zealand economy from the weakness that was recorded during 1997-98. One common theme in the labour market over the past two years has been the uneven nature of the recovery, both across sectors and over time.
\end{abstract}

Keywords: Employment growth, unemployment rate, real wage growth.

The purpose of this paper is to set the scene for the Ninth Conference on Labour, Employment and Work1. The paper will present trends that have been observed in the New Zealand labour market over the past 15 years and put recent changes in the labour market in the context of the business cycle. What this paper will not do is attempt to offer any new explanations, but as much as possible, to present the data descriptively and offer other people's explanations for the changes.

The structure of this paper is to firstly examine trends in the New Zealand economy and labour market over the past 15 years. In these sections economic growth, employment growth and unemployment rates are examined. From there, trends in the sub-sections of the labour market are examined. The trends examined are in the trends in industrial and occupational composition of the New Zealand economy, hours of work, disparities, wage growth and the gender pay gap. Finally, some future directions in the labour market and possible future research in the area is examined.

\section{Trends in Economic Growth}

New Zealand's economic growth over the past 15 years is often split into two periods. The first period (1984-1992) is referred to as a period of structural adjustment when the New Zealand economy went from being a highly regulated and interventionist economy to being more open and market-based. These reforms have been well documented (see Silverstone, Bollard and Lattimore (1996)). In this period, there was a tightening of monetary policy to stabilise inflation, there was the removal of a number of protections for domestic producers and the public sector was restructured (Mare (1996)). In the period 1984-92 economic growth was highly variable and was relatively low on average (see figure 1) and there was considerable change in the structure of the New Zealand economy. Annual economic growth in this period averaged 0.4 percent.

The second period (1993-2000) is often seen as the period when New Zealand reaped the benefits from the reforms of the first period, or alternatively, it is seen as a period of recovery from the particularly poor performance of the New Zealand economy during the late 1980 s and early 1990s. During the mid-1990s New Zealand experienced a period of sustained and stable economic growth. The economic growth was stimulated by robust global growth, low interest rates and exchange rates, a cyclical recovery, an increasing propensity for households to take on debt and rising household disposable income (from an improving labour market). The annual average economic growth in this period was 3.3 percent.

The success or failure of New Zealand's economic performance and reforms over the past 15 years depends on how you weight the different periods (Mare' (1996)), which point in time you chose to start your analysis and your view of the role of government policy in this process. However, more generally it can be concluded that during the second half of the 1980s New Zealand experienced weak and variable economic growth, while during the 1990 s economic growth, as measured by Gross Domestic Product, was stronger and more stable.

Over the past two years, the New Zealand economy has recorded solid economic growth, although the growth has been uneven over the period. The New Zealand economy has recovered from the weakness observed during 1998, which occurred as a result of drought, the Asian Financial 


\section{Figure 1. Economic Growth in New Zealand (1985-2000)}

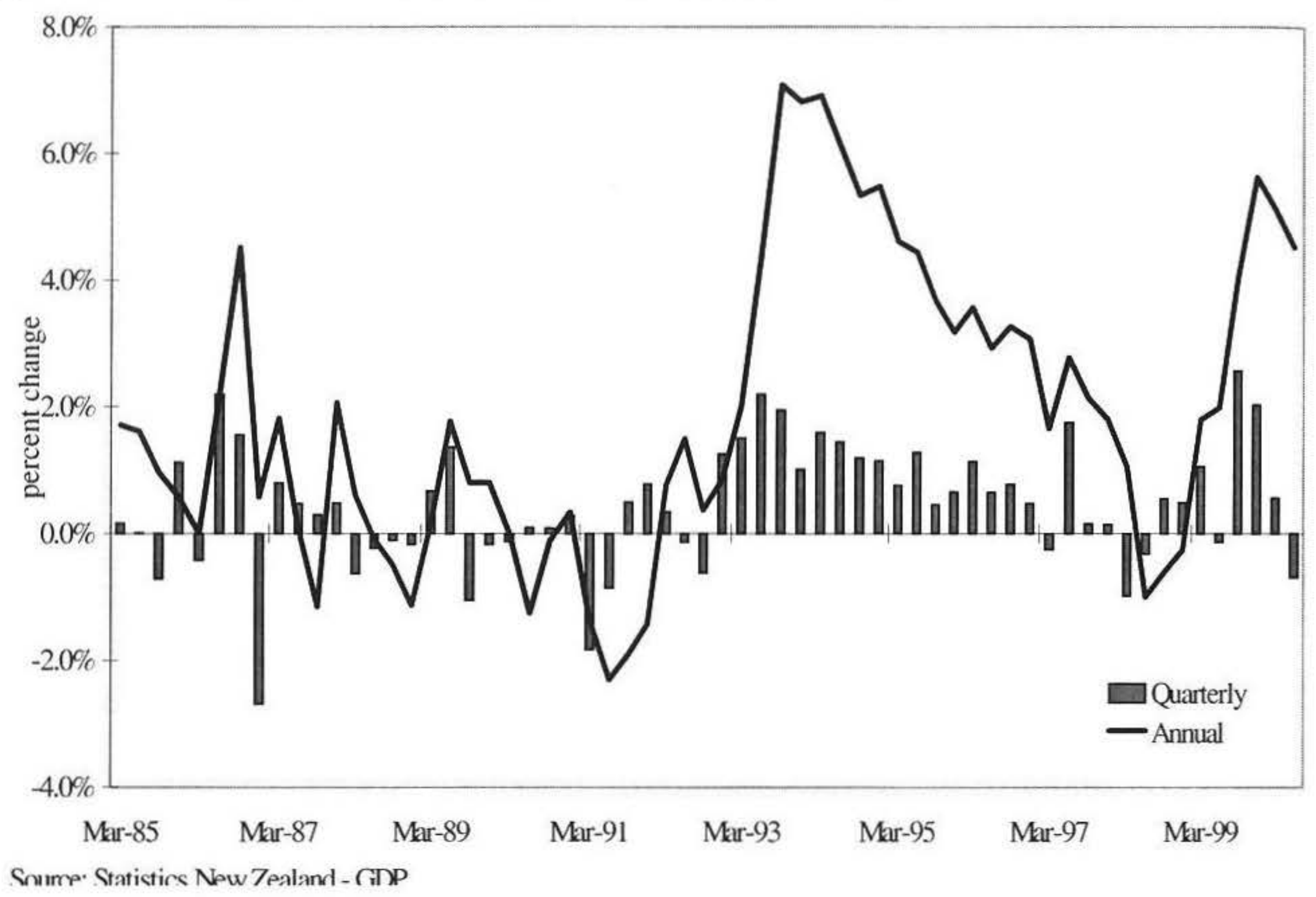

crisis and tight monetary conditions. The key drivers of the economic growth over the past two years have been the strengthening world economy, good growing conditions for farmers, a number of one-off events and reasonably loose monetary conditions. Over the past year the economy has grown by annual average 4.8 percent, with particularly strong growth in investment (up 9.7 percent), imports (up 9.7 percent) and exports (up 8.7 percent).

Underneath this general picture of robust economic growth over the past two years there has been considerable volatility in quarterly results. This has partly been the result of a number of temporary events, aseasonal patterns in agriculture and the normal volatility associated with quarterly survey estimates. The temporary events in this period include $\mathrm{Y} 2 \mathrm{~K}$, millennial celebrations, APEC, exceptional growing conditions for farmers and the America's Cup. There was a surge in residential construction in the March 2000 quarter, which was then reversed in the June 2000 quarter, which also lead to some volatility in GDP estimates during 2000.The aseasonal patterns in agriculture have been influenced by the recovery from consecutive droughts in 1997-98 and 1998-99 and exceptional growing conditions in 1999-00. Over the last three June quarters New Zealand has recorded negative economic growth, but - offsetting this - New Zealand recorded strong economic growth in the September 1999 and December 1999 quarters.

Figure 2 shows that New Zealand's employment growth has tended to follow economic growth closely. The weak and variable economic growth during 1986-92 was reflected in weak and variable employment growth and the stronger economic growth in the period 1993-2000 was reflected in stronger and less variable employment growth. However, in the period 1993-2000 employment growth was particularly strong given the strong economic growth. In addition, in this period there was the surprising result of strong economic growth being associated with negative productivity growth, meaning that employment growth was particularly strong in the period.

\section{Trends in Unemployment and Labour Force Participation}

Over the past 15 years, changes in New Zealand's unemployment rate and labour force participation rate, like employment growth, have to a large extent reflected economic performance. During the period 1986-92, the New Zealand unemployment rate rose steeply from a low point of 4.0 percent in the December 1985 quarter to a peak of 10.9 percent in the September 1991 quarter (see figure 3), according to the Household Labour Force Survey (HLFS). This occurred at a time of weak economic growth. In this period New Zealand's labour force participation fell from 66.9 percent to 63.8 percent. It would be expected that with deteriorating job prospects in times of weak economic growth, some people would stop actively looking for work and move out of the labour force, thereby lowering the labour force participation rate.

During the period 1992-96, New Zealand experienced more robust economic growth and the unemployment rate fell from 10.9 percent to 6.0 percent in the December 1996 quarter. In this period New Zealand's labour force 
Figure 2. Employment Growth and Economic Growth (1986-2000)

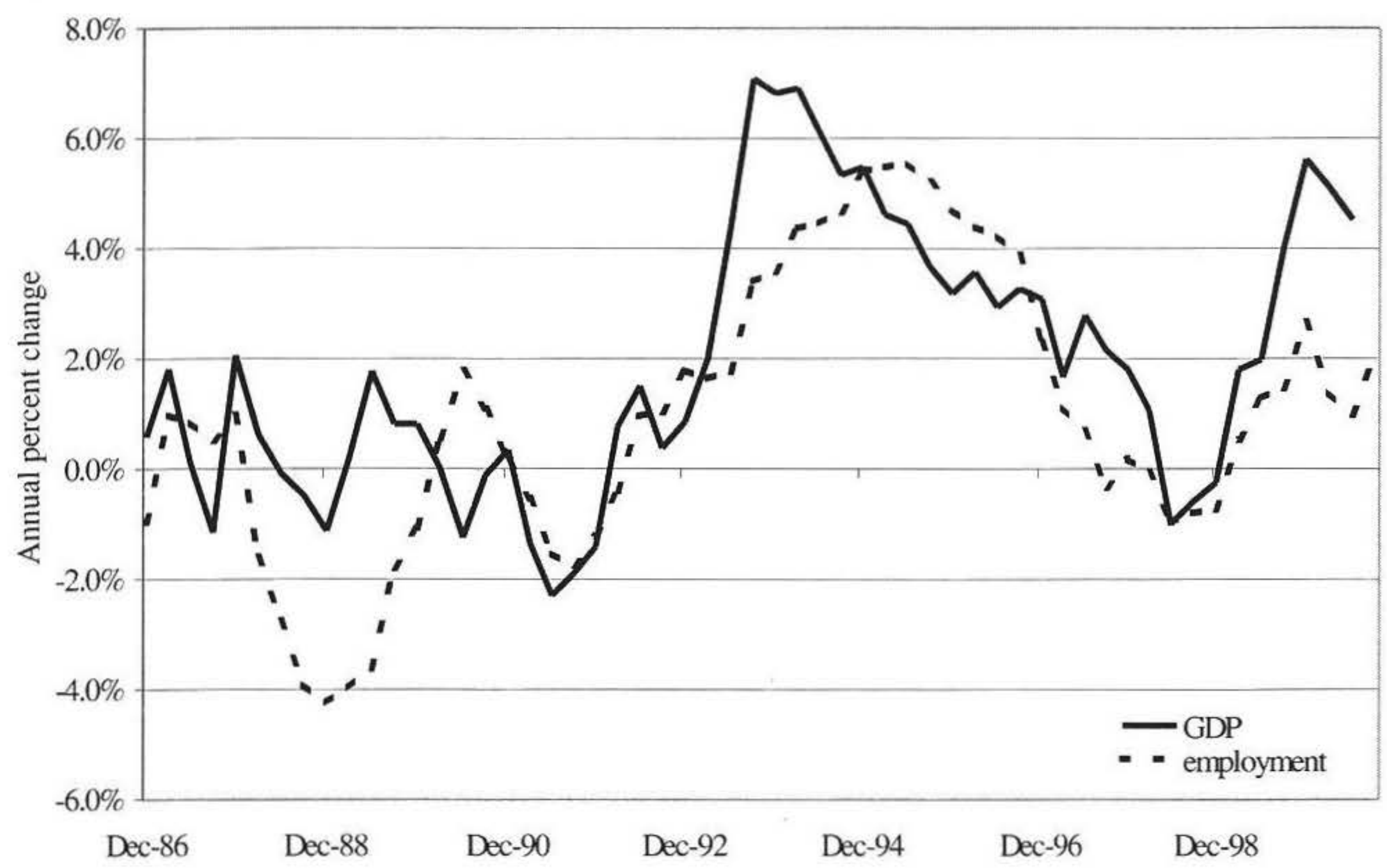

Source: Statistics New Zealand - GDP; HLFS

Figure 3. Unemployment Rate and Labour Force Participation Rate (1985-2000)

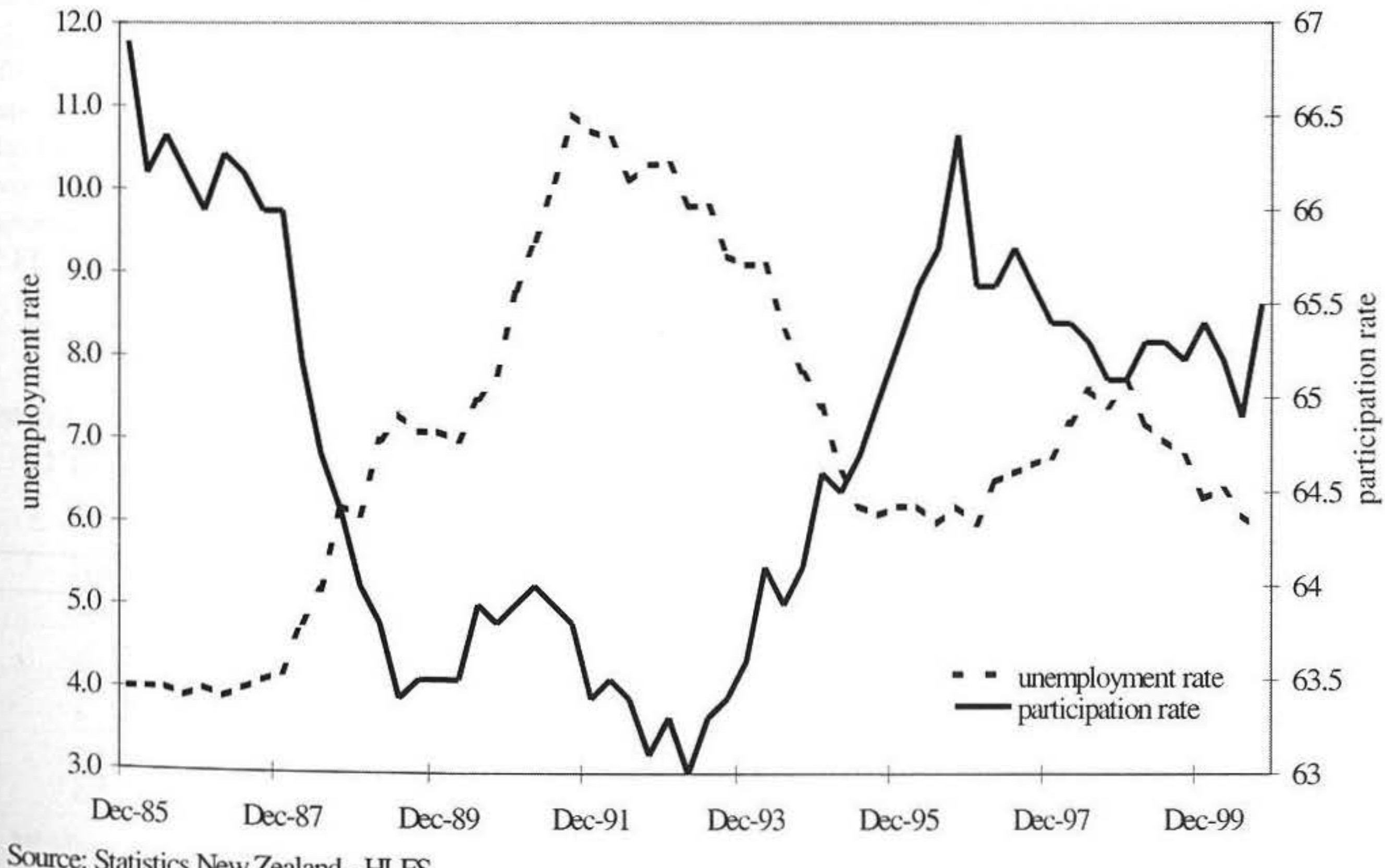

Source: Statistics New Zealand - HLFS 
participation rate increased again from 63.8 percent to 65.6 percent. In the period 1996-98 New Zealand experienced weaker economic growth which led to the unemployment rate increasing from 6.0 percent to 7.7 percent in the December 1998 quarter. In this period New Zealand's labour force participation fell from 65.6 percent to 65.1 percent.

Since the December 1998 quarter New Zealand has experienced solid employment growth, which has led to a gradual fall in the unemployment rate. Over the past 18 months, employment has increased 3.5 percent; there has been only moderate growth in population due to net outmigration, which has partially offsetting the natural increase, and only a moderate increase in the labour force participation rate from 65.1 percent to 65.5 percent. Together these factors have led to a fall in New Zealand's unemployment rate from 7.7 percent in the December 1998 quarter to 5.9 percent in the September 2000 quarter. New Zealand's current unemployment rate is close to the rates observed during 1996 when it fluctuated at rates around 6.0 percent.

\section{Industry and Occupational Trends}

Over the past decade the New Zealand labour force has moved away from goods producing industries (agriculture and manufacturing) towards services industries (community and personal services and business and financial services) (see figure 4). This trend in the New Zealand labour market towards services industries is common to many OECD countries. Since 1987 the proportion of employment in agriculture and manufacturing has fallen from 32.9 percent to 25.4 percent (see Carroll (forthcoming)). At the same time, the proportion of employment in distribution has increased from 26.0 percent to 28.6 percent, in community and personal services has increased from 25.4 percent to 27.3 percent and the proportion of employment in other services has increased from 15.8 percent to 18.7 percent.

Over the past eight years there has been a movement towards professional occupations and service and sales occupations in New Zealand ${ }^{2}$. This change in the composition of occupations could be expected with the changing industrial structure of the New Zealand economy. Over the past nine years the proportion of the workforce classified as professionals has increased from 35.8 percent in the year ended December 1991 to 38.5 percent in the year ended September 2000, while the proportion of service and sales workers increased from 13.1 percent of the workforce to 15.4 percent of the workforce. The proportion of the workforce who are clerks fell from 14.5 percent to 11.8 percent and the proportion of plant and machinery, agriculture and trades workers fell from 30.2 percent of the work force to 27.5 percent.

\section{Hours of Work}

There has been a trend away from people working 40 hours per week, according to the HLFS. The usual hours of paid work ${ }^{3}$ for both males and females have been changing. While for both males and females a significant proportion are still employed for 40 hours per week, there has been a move away from 40 hours per week toward either end of the spectrum (see figure 5). This trend may reflect changing firm needs, or it may reflect people's changing preferences toward paid employment and leisure.

Overall, evidence of a continued 40 hour standard working week is mixed. There are recorded to be around 496,500 people employed usually working 40 hours per week. This leaves around 1,230,000 people employed not usually working 40 hours per week. There appears to be a growing range of employment opportunities covering both less than 40 hours per week and more than 40 hours per week. The drivers behind these changes are not clear, but it is likely to include both changes in regulation affecting services (e.g. shopping) combined with changing consumer preference for longer shopping hours and the changing industrial structure of the New Zealand economy towards industries which require more flexibility or longer hours of work. In addition, more people are combining employment with other activities such as study (either through choice or necessity) and childcare. A further factor is that the professional sector is increasing as a share of employment and professionals tend to work longer hours.

\section{Unemployment Concentration}

Although New Zealand's aggregate unemployment rate currently stands at 5.9 percent of the labour force, there is considerable variation in unemployment across different groups (see table 1). The male unemployment rate currently stands at 6.1 percent, the unemployment rate for 15-24 year olds stands at 12.3 percent, the unemployment rate for people with no qualifications is 10.6 percent and the Maori unemployment rate currently stands at 14.1 percent, according to the HLFS.

\section{Table 1. Unemployment Rates Across Different Groups (Year to September)}

\begin{tabular}{lccc}
\hline & $\mathbf{1 9 8 6}$ & $\mathbf{1 9 9 3}$ & $\mathbf{2 0 0 0}$ \\
\hline Total & 4.0 & 9.8 & 6.2 \\
Professionals & na & 2.8 & 2.4 \\
Northland & na & 12.7 & 8.9 \\
No qualifications & 6.3 & 15.5 & 10.6 \\
Pacific peoples & 7.2 & 25.5 & 11.7 \\
Youth (15-24 year & 7.9 & 17.5 & 13.0 \\
olds) & & & \\
Maori & 10.1 & 23.4 & 14.1 \\
\hline
\end{tabular}


Figure 4. New Zealand's Industry Composition (1986/2000)

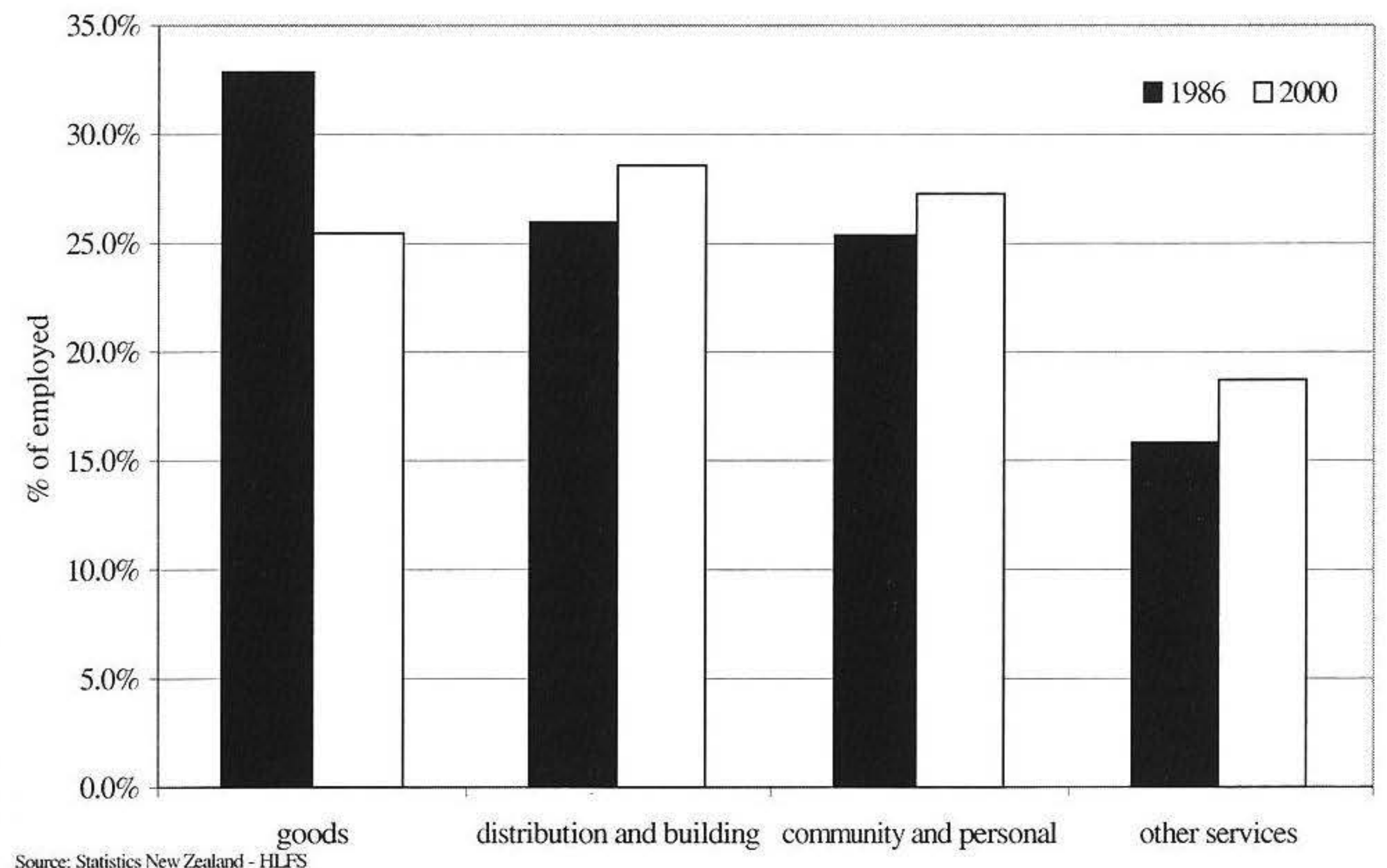

Figure 5. Distribution of Weekly Hours Workers (1987/ 1999)

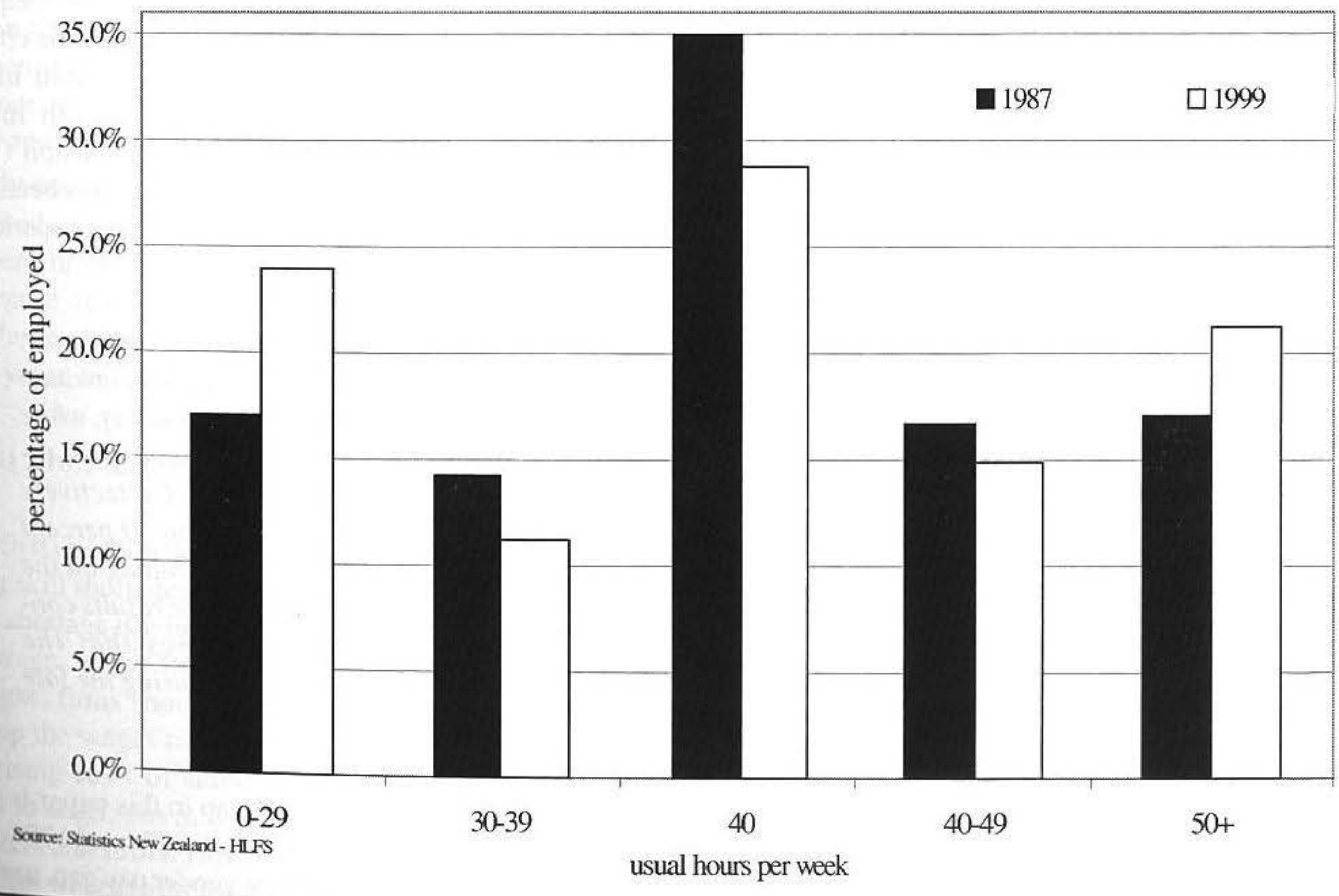


Table 1 shows that the movements in unemployment rates for different groups have followed the aggregate unemployment rate, but to varying degrees. With groups that tend to have higher unemployment rates seeing a larger percentage point increase in their unemployment rates in the period 1986-93 and then these groups having larger percentage point decreases in their unemployment rates in the period 1993-2000.

Chapple and Rea (1998) examine the disparity between and Maori and non-Maori labour market outcomes in the Household Labour Force Survey. They conclude that while relative labour market performance for Maori was considerably worse in 1998 than in 1985 , that most of the deterioration occurred between 1985 and 1992 and that between 1992 and 1996 there was some recovery in relative Maori performance.

Humphris and Chapple in this voulme examine the disparity between Pacific and Non-Pacific Peoples' labour market outcomes in the Household Labour Force Survey. Their paper shows that today Pacific people have a lower employment rate than non Pacific people. However, in 1986 the Pacific employment rate was higher than the employment rate for non Pacific peoples. Pacific employment disparity rose substantially at the end of the 1980 s, to peak at around 15 percent at the end of 1991. It has since been falling slowly to the present level of approximately 8 percent. They conclude that changes in labour demand appeared to have a strong influence and found that part of the change in employment disparity could be explained by changing labour demand in sectors in which Pacific people were over-represented.

The Labour Market Policy Group of the Department of Labour is currently undertaking a project to investigate unemployment dynamics and the effect of active labour market assistance (see Gobbi and Rea in this volume). The research is based on a newly created longitudinal dataset of all individuals who were registered unemployed over the period October 1988 to December 1997. Some generalised findings of this research are: a small proportion of job seekers experience very long spells of unemployment; after ending a spell of unemployment, a proportion of job seekers become unemployed again relatively quickly; multiple spells of unemployment are common; and; there is a core of job seekers whose experience of unemployment is chronic. These individuals experience repeated spells of unemployment and spend years rather than months unemployed.

\section{Wages}

Over the past 10 years wage nominal wage growth has to a large extent reflected the tightness in the New Zealand labour market and the degree of inflationary pressure. There tends to be a lag between developments in wage growth and changes in the economy, partly as wage settlements are often infrequent. Taking a broad look at the labour market during the early 1990s, nominal wage growth was robust due to the continued high inflation; it weakened in the period 1992-94 due to low inflation and a weak labour market; in 1995-97 inflation was slightly higher and the labour market was tight, which led to strong nominal wage growth (see figure 6). In the period 1998 . 00 wage growth was moderate as labour market recovery and rising inflation were yet to feed through to increasing wage pressure.

At the aggregate level, wage growth has been moderate in the year to September 2000. The Quarterly Employment Survey (QES) reported that growth in total average hourly earnings was 1.7 percent in the year to August 2000, down from 2.1 percent in the year to May 2000. In comparison, the Labour Cost Index (LCI) indicated that total wage growth was 1.5 percent in the latest year, compared to 1.6 percent in the year to June 2000.

Over the past year wage growth has been strongest for professionals (annual wage growth was 2.7 percent for professionals in the year to September 2000), with wage growth for other occupations being slightly weaker $(0.9$ percent for clerks and service and sales workers and 1.4 percent for other occupations), according to the LCI. The key driver of the strong wage growth for professionals was the wage settlements for teachers that occurred during 1999 (annual wage growth for teachers was 4.5 percent for the year to September 2000). The fact that professionals gained stronger wage growth than other workers over the past year continues the trend of the period 1995-2000.

With the stronger wage growth for professionals (who are a highly paid group) over the past ten years it raises the question what has been happening to income inequality over time. Hyslop and Mare' (2000) examine the changes in the distribution of New Zealand household income between 1983-86 and 1995-98. The rise in income inequality has been widely reported (see Easton (1996) and Statistics New Zealand (1999)) and it has been large in comparison with other developed countries' experiences. Hyslop and Mare' (2000) conclude that:

Changes in household structure, attributes,
and employment outcomes each contribute
to the observed increase in inequality, while
the changes in returns are estimated to re-
duce the level of inequality. Collectively
these factors account for about 50 percent
of the observed increase, depending on the
measure of inequality used. The results con-
firm other research findings that the
changes were concentrated during the late
1980s.

The analysis on the gender pay gap in this paper is taken directly from Dixon (2000). Between 1984 and 1998, there was a substantial reduction in the gender pay gap, as measured by average hourly earnings. Taking the HES figure for 1984 and the IS figure for 1999, women's average 


\section{Figure 6. Annual Total Wage Growth (1990-2000)}

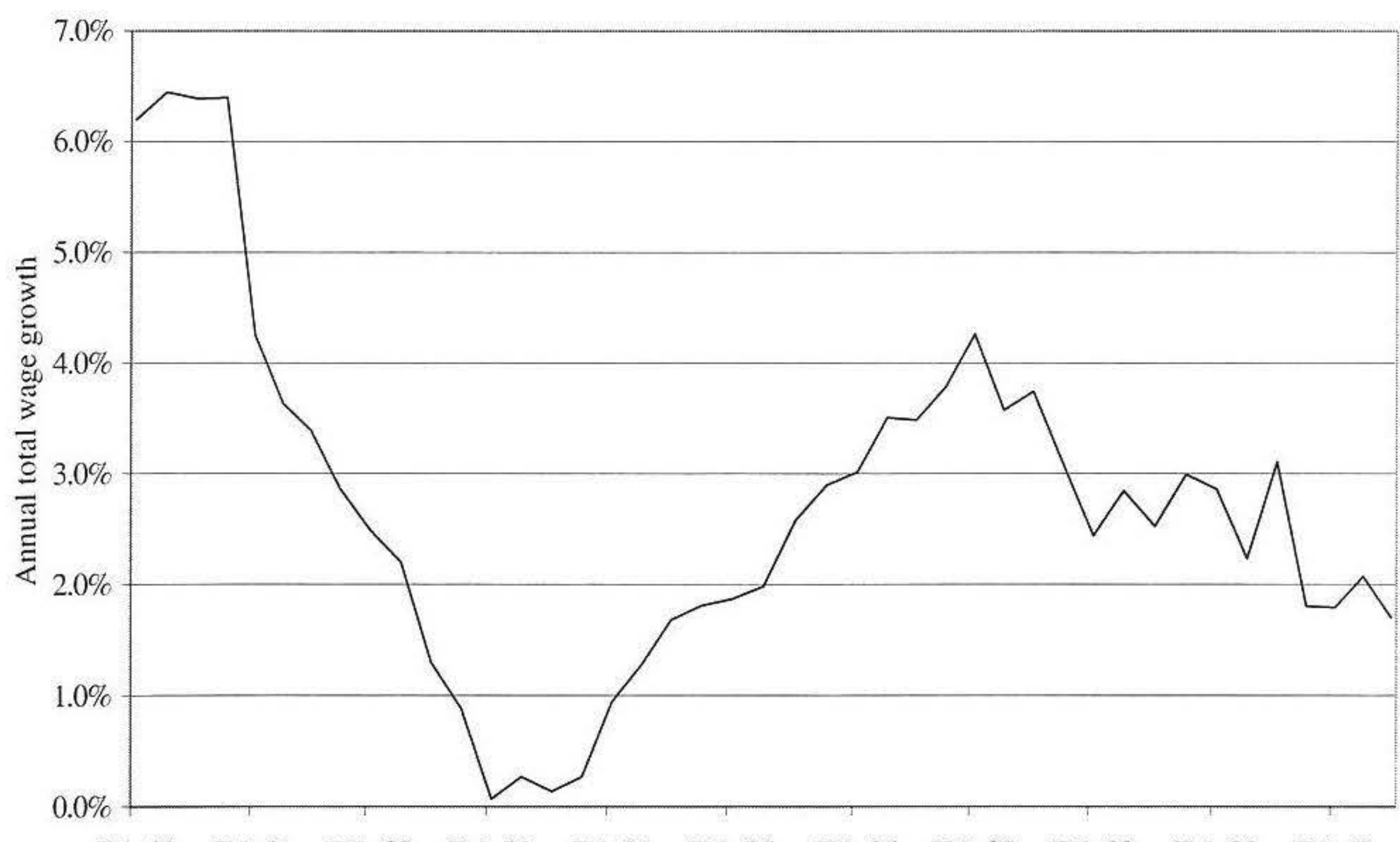

Feb-90 $\quad$ Feb-91 $\quad$ Feb-92 $\quad$ Feb-93 $\quad$ Feb-94 $\quad$ Feb-95 Feb-96 $\quad$ Feb-97 $\quad$ Feb-98 $\quad$ Feb-99 $\quad$ Feb-00

Source: Statistics New Zealand - QES

hourly earnings were 79 percent of men's in 1984, and 86 percent in 1999. The gender gap in weekly earnings also declined. The average weekly earnings of full-time employed women were 74 percent of men's in 1984, and 81 percent in 1999. The gender gap in weekly earnings is larger than the gender gap in hourly earnings because men tend to undertake paid work for more hours per week. Dixon (2000) estimates that the gaps between men and women in average level of qualifications and average years of prior work experience can account for between onethird and three-fifths of the gender differential in average hourly earnings in the late $1990 \mathrm{~s}$. Differences in industrial and occupational composition could account for 2040 percent of the gender pay gap in the late 1990s. The industrial and occupational profiles of male and female employment have become more similar over the last fifteen years, but the differences remain substantial.

\section{Skill Shortages}

The first question that needs to be addressed when examining skill shortages is what exactly is a skill shortage? A skill shortage is a lack of skilled labour at the going market wage. In the long-term (according to one school of thought) firms should compete amongst themselves and bid up the wages of skilled labour. In combination with the rising costs of skilled labour and the increasing returns to skills, this may lead to increased training by both workers and firms. However, in the short-run it will take time for wages to adjust and there may be reasons that the adjustment in terms of increased training does not take place as completely as suggested by theory (such as poor information about the labour market and the long-term nature of occupational choice).

The most commonly used indicators of skill shortages are from NZIER's Quarterly Survey of Business Opinion (QSBO). The two indicators from the QSBO are both relative measures of skill shortages. The first indicator measures the net percentage of firms who report an increase in the difficulty of finding skilled labour in the current quarter compared to the previous quarter (i.e. the skill shortage in the current quarter relative to the previous quarter). The second indicator measures the percentage of firms whose primary constraint on the expansion of output is labour (i.e. skill shortages (labour) as a constraint on output relative to other inputs).

Taking these indicators at face value, it can be seen that skill shortages tend to follow movements in the unemployment rate quite closely. When the unemployment rate was rising sharply between 1987 and 1991 skill shortages were at a relatively low level, but with the tightening in labour market conditions between 1991 and 1996 skill shortages increased. With the unemployment rate falling between 1996 and 1998, the measures of skill shortages fell and then with the recovery in the labour market since 1998 skill shortages have increased to levels approaching those recorded in the mid-1990s (see figure 7). 
Figure 7. Skill shortages (1985-2000)

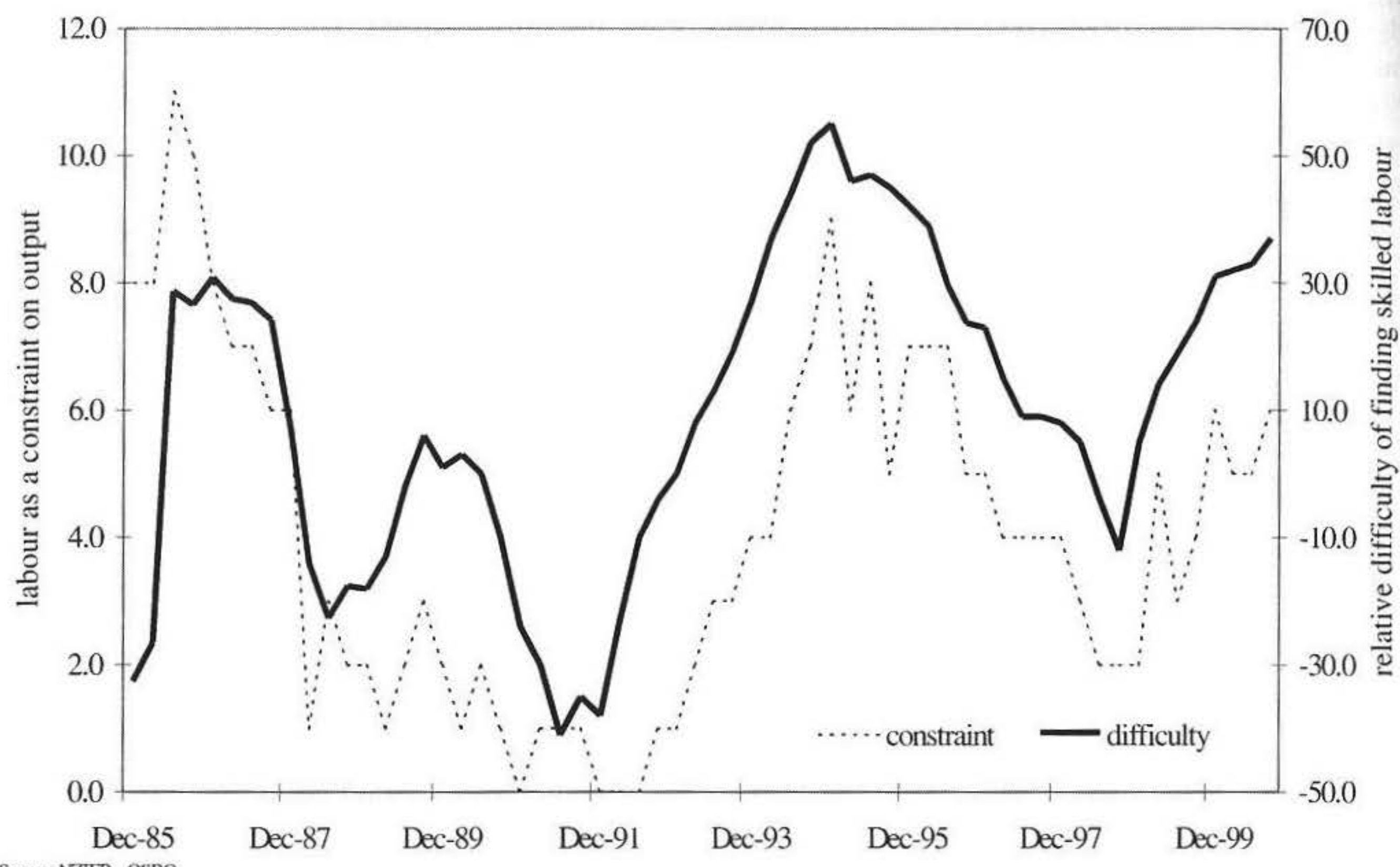

\section{What Can We Conclude from Recent Changes in the New Zealand Labour Market?}

So far this paper has presented statistics that show that during the late 1980s and early 1990s New Zealand recorded moderate and variable economic growth, while during the 1990s New Zealand economic growth has been stronger and less variable. Changes in the New Zealand labour market have to a large extent reflected changes in the New Zealand economy (with possible feedback from the labour market to economic performance), with a deterioration in outcomes in the late 1980s and early $1990 \mathrm{~s}$ and a recovery in outcomes during most of the 1990s. In recent times there was a slow down in economic growth in 1997-98 due to a number of factors and since 1998 there has been a recovery in both economic and labour market outcomes.

Looking at two summary measures of labour market performance (the unemployment rate and labour force participation) we can probably conclude that the New Zealand labour market is currently performing at a level at least as strongly as in the mid-1990s and possibly slightly stronger (New Zealand's unemployment rate is slightly lower than during the mid-1990s, but labour force participation is also slightly lower). However, at the aggregate level it is not performing as strongly as it was in the period 1985-87 when both the unemployment rate and labour force participation indicated a stronger labour market. In terms of disparities a similar story can probably be told with the disparities between groups at their lowest levels since the late 1980s, but still some way off the level achieved in 1985-87.

As in 1996 when Mare' (1996) presented a similar paper to the $7^{\text {th }}$ LEW conference, there are two main positions on New Zealand's recent labour performance. The first position focuses on the last 9 years and concludes that the New Zealand economy and labour market has performed more strongly than in the $1970 \mathrm{~s}$ and 1980 s, although some vulnerabilities remain; see Conway and Orr (1999), OECD (1999). The second position focuses on the last 15 years and concludes that New Zealand's performance over this period has been weaker than in many other OECD countries over the same period and that there were large adjustment costs to the new macroeconomic and labour market framework (see Gregory (1999)). The two stories are not necessarily inconsistent, but what it does show is that there are two different interpretations of New Zealand's recent economic and labour market performance.

\section{Looking Forward}

The most likely path for the economy in the period 200102 appears to be firm economic growth led by robust export growth (with a low exchange rate and positive global growth). However, economic growth may remain moderate for the remainder of 2000 due to weakness in the domestic economy. In spite of this general picture, major risks surround the performance of the domestic economy over the next two years, particularly given the low levels of 
business and consumer confidence and the current weakness in the housing market (it is expected to remain relatively weak given the apparent over-supply in the market and the net outward migration figures). A weak housing market would slow economic growth directly through lower household construction and indirectly through reducing household wealth (and therefore consumption). Indicators released in mid-2000 suggest that construction and household expenditure may significantly slow GDP growth. However, rising export earnings are likely to feed through to improved overall economic performance from mid-2001. Overall, according to the NZIER Consensus forecast economic growth is expected to be around 3 percent during 2001 and 2002.

Given that New Zealand's labour market performance over the past 15 years has been closely related to economic outcomes, it is likely that there will be a further improvement (tightening) in labour market conditions. This strengthening in labour market conditions is expected to lead to a small fall in the unemployment rate, rising labour force participation and increasing wage growth. In the past unemployment rate differences have tended to narrow during times of a strengthening labour market and disparities across groups may reduce further over the next two years. However, as with any outlook, there remain a number of risks including softening growth in the US, low business and consumer confidence and the weak housing market which may slow economic growth and therefore further labour market recovery.

\section{Future Research}

In the area of future research into labour market trends a key question, as raised by Melville (1998), is how much of the economic growth and associated improvement in labour market outcomes is the result of changes in government policy and how much is the result of other underlying changes in the economy. Another area for future research is how much of a concern are the trends that have been observed. Is it a concern that there are fewer people working 40 hours per week? Is it a concern that more people are working in the services industries? One way to answer these questions is to examine the characteristics of the jobs: are they well paid, are the conditions satisfactory and are people being pushed into the jobs or are they choosing to work in them?

\section{Notes}

1 Patrick Conway is an Adviser and Nick Carroll is an Assistant Analyst at the Labour Market Policy Group of the Department of Labour. The views expressed in this paper are those of the authors and not necessarily those of the Department of Labour.

2 The analysis is for the period since 1991 as consistent occupational codes have been used in the Household Labour Force Survey only since this time.
3 The analysis of usual hours worked is by people employed which covers, paid employees, employers, self-employed without employees, and those who are unpaid but work for a family business.

\section{References}

Carroll, N. (1999) Labour Market Trends and Outlook. Labour Market Bulletin 1999.

Chapple, S. and Rea, D. (1998) Time series analysis of disparity between Maori and non-Maori labour market outcomes in the Household Labour Force Survey. Labour Market Bulletin 1998. 1,2

Conway, P. and Orr, A. (1999) The process of economic growth in New Zealand. Reserve Bank of New Zealand: Bulletin. 62 (1).

Dixon, S. (2000) Pay Inequality between Men and Women in New Zealand. Department of Labour Occasional Paper, 2000/1.

Easton, B. (1996) Income Distribution. Silverstone, B. Bollard, A. and Lattimore, R. (Eds). A Study of Economic Reform: The Case of New Zealand. North-Holland.

Gobbi, M. and Rea, D. (2001) The Nature of Unemployment in New Zealand: Dynamics of the 1993 Cohort. Morrison, P.S. (ed.) Labour, Employment and Work in New Zealand. Proceedings of the Ninth Conference Institute of Geography, Victoria University of Wellington.

Gregory, B. (1999) Labour Market Outcomes in the UK, NZ, Australia and the US: Observations on the Impact of Labour Market and Economic Reforms. Bell, S. (Ed) The Unemployment Crisis: Which Way Out? Cambridge University Press.

Humphris, J. and Chapple, S. (2001). An Analysis of Disparity between Pacific and Non-Pacific Peoples' Labour Market Outcomes in the Household Labour Force Survey. Morrison, P.S. (ed.) Labour, Employment and Work in New Zealand. Proceedings of the Ninth Conference Institute of Geography, Victoria University of Wellington.

Hyslop, D. and Mare', D. (2000) Understanding Changes in the Distribution of Household Incomes in New Zealand Between 1983-86 and 1995-98. Center for Labour Economics, University of California, Berkeley, Working Paper no. 24.

Mare', D. (1996) Labour Market Trends, Cycles and Outlook. Morrison, P.S. (ed.) Labour, Employment and Work in New Zealand. Proceedings of the Seventh Conference Institute of Geography, Victoria Uni- 
versity of Wellington.

Melville, D. (1998) The New Zealand labour market: recent trends and future prospects. Morrison, P.S. (ed.) Labour, Employment and Work in New Zealand. Proceedings of the Eighth Conference Institue of Geography, Victoria University of Wellington.

OECD (1999). OECD economic survey: New Zealand, 1999. Paris: OECD.

Silverstone, Bollard and Lattimore (Eds.) (1996) A Study of Economic Reform: The Case of New Zealand. North-Holland.

Statistics New Zealand (1999), New Zealand Now. Wellington: Statistics New Zealand.

\section{Authors}

Patrick Conway

Acting Manager Opportunities

Labour Market Policy Group

Department of Labour

PO Box 3705

Wellington

Patrick.Conway@lmpg.dol.govt.nz

Nick Carroll

Trainee Analyst

Labour Market Policy Group

Department of Labour

PO Box 3705

Wellington

Nick.Carroll@lmpg.dol.govt.nz 